Н. Ф. Павлюкова, В. Н. Кучма

Днепропетровский нацииональный университет

\title{
ИЗМЕНЕНИЕ АГРОХИМИЧЕСКИХ СВОЙСТВ ПОЧВЫ ПРОМЫШЛЕННОГО УЧАСТКА, ЗАГРЯЗНЕННОГО ФТОРИДАМИ
}

\begin{abstract}
Вивчено зміни деяких агрохімічних властивостей грунтів моніторингових ділянок поблизу підприємств, в атмосферних викидах яких домінують фториди. Встановлено залуження грунтової витяжки едафотопів промислового майданчика. Показано зменшення вмісту рухомих форм фосфору, азоту (нітратних i нітритних сполук), гумусу у грунті моніторингових ділянок при збільшенні концентрації азоту амонійних сполук.
\end{abstract}

The changes of some agrochemical properties of soils of model plots closed to industrial enterprises with fluoride atmospheric emissions were studied. The alkalescence of soils at the plots was found. The reduction of content of the mobile forms of phosphorus, nitrite and nitrate forms of nitrogen and humus level in soil is caused by the increasing amount of nitrogen of ammonium compounds.

\section{Введение}

Поступление фторидов в ландшафты связано с тем, что они являются одним из основных компонентов промышленных выбросов предприятий по производству алюминия, цветных металлов, стекла и керамики. Кроме того, повышенное содержание фтористых соединений в почвах вызвано внесением фосфорных удобрений и мелиорантов, в которых фтор составляет от 0,3 до 4 \% [2; 8]. Длительное применение фосфорных удобрений на мощном черноземе увеличило содержание в нем фтора на $22-28 \%$ [1; 9]. Поступление в почвы газообразных фторидов из атмосферных промышленных выбросов обусловлено тем, что почва находится в состоянии динамического равновесия с приземным слоем атмосферного воздуха и выступает как в роли поглотителя газов, так и их продуцента $[7 ; 10]$.

Наиболее высокое содержание фтора, превышающее фоновый в 8 и более раз по растворимому, в 5 и более раз по валовому показателю, находится на ближайших расстояниях от завода по переработке фосфатных концентратов и руд. С удалением от источника эмиссий валовое содержание фтора уменьшается и на расстоянии 12 15 км приближается к фоновому уровню [4; 5].

В работах по экологическому районированию территории Днепропетровской области указывается, что фтор относится к одному из приоритетных загрязнителей [3]. Процессы урбанизации превращают природные экосистемы в специфические, так называемые индустриальные экосистемы. Изучение состояния почв этих экосистем имеет большое значение. Анализ доступных нам литературных источников показал, что вопрос о накоплении фторидов кислого характера и их влиянии на физикохимические свойства черноземных почв практически не изучен.

Цель данной работы - выявить изменения некоторых агрохимических свойств почв мониторинговых участков вблизи предприятия, в атмосферных выбросах которого превалируют фториды.

\section{Материал и методы исследований}

Почву для исследований отбирали с разрезов двух мониторинговых участков, один из которых расположен на значительном расстоянии (40 км) от Запорожского алюминиевого комбината и считается условно чистым. Второй участок был заложен

(C) Н. Ф. Павлюкова, В. Н. Кучма, 2007

Вісник Дніпропетровського університету. Біологія, екологія.

Vìsnik Dnìpropetrovs'kogo unìversitetu. Seriâ Bìologîa, ekologîâ Visnyk of Dnipropetrovsk University. Biology, ecology. Vìsn. Dnìpropetr. Unìv. Ser. Bìol. Ekol. 2007. 15(1).

ISSN 2310-0842 print ISSN 2312-301X online www.ecology.dp.ua 
вблизи цеха по выплавке алюминия, в производственных выбросах которого доминируют фториды. По морфологическому описанию почва мониторингового участка вблизи цеха по выплавке алюминия значительно отличается от зональной почвы (чернозема южного) тем, что почвенные горизонты перемещены, имеют значительное количество включений строительного мусора. Почву из разрезов отбирали через каждые 10 см профиля и подготавливали к анализу. Содержание гумуса, $p H$ водной вытяжки определяли по общепринятой методике [6], содержание азота аммонийных форм - с реактивом Несслера, нитратных, нитритных - методом Грандваль-Ляжу с сульфаниловой кислотой и альфа-нафтолом. Определение подвижных форм фосфора выполняли по методу Чирикова [6].

\section{Результаты и их обсуждение}

Исследования почвенного гумуса проводятся для оценки плодородия почв по следующим основным показателям: его процентному соотношению, общим запасам, распределению по профилю. Определение содержания гумуса в почвенном профиле чернозема юного на условно чистом участке позволило установить, что наибольшее его содержание приурочено к верхним слоям (2,94-3,48 \%). Уменьшение концентрации гумуса вниз по профилю происходит постепенно, за исключением слоя 60-70 см. Такая закономерность наблюдается и в почве опытного участка, находящегося у цеха по выплавке алюминия. Во всех слоях почвы его содержание статистически достоверно уменьшается по сравнению с таковым для зональной почвы (табл.).

Таблица

Содержание ${ }^{1}$ гумуса, подвижных форм фосфора, азота аммонийных, нитритных и нитратных форм в почве условно чистого участка и в почве у цеха по выплавке алюминия

\begin{tabular}{|c|c|c|c|c|c|c|c|c|c|c|}
\hline $\begin{array}{c}\text { Глубина, } \\
\text { см }\end{array}$ & Гумус, \% & $\begin{array}{c}t_{\text {on }} / \\
t_{\text {maбan. }}\end{array}$ & $\begin{array}{c}P_{2} O_{5} \text { мг/ } \\
100 \text { г сухой } \\
\text { почвы }\end{array}$ & $\begin{array}{c}t_{\text {on }} / \\
t_{\text {mán }}\end{array}$ & $\begin{array}{c}N-N H_{4}^{+} / \\
100 \text { г сухой } \\
\text { почвы }\end{array}$ & $\begin{array}{c}t_{\text {on }} \\
t_{\text {maбin. }}\end{array}$ & $\begin{array}{c}N-N O_{2} / \\
100 \text { г сухой } \\
\text { почвы }\end{array}$ & $\begin{array}{c}t_{\text {on }} / \\
t_{\text {maб̆лn. }}\end{array}$ & $\begin{array}{c}N-N O_{3} / \\
100 \text { г сухой } \\
\text { почвы }\end{array}$ & $\begin{array}{c}t_{\text {on }} / \\
t_{\text {maбn. }}\end{array}$ \\
\hline $0-10$ & $\frac{3,48 \pm 0,16}{2,37 \pm 0,26}$ & $3,6^{*}$ & $\frac{142,13 \pm 0,36}{36,41 \pm 0,98}$ & $10,2^{* * *}$ & $\underline{5,77 \pm 0,05}$ & $3,7^{*}$ & $\begin{array}{l}\underline{0,76 \pm 0,01} \\
0,08 \pm 0,05\end{array}$ & $1,4^{*}$ & $\begin{array}{l}\underline{0,41 \pm 0,03} \\
0,02 \pm 0,01\end{array}$ & $5,5^{* *}$ \\
\hline $10-20$ & $\frac{2,94 \pm 0,09}{1,45 \pm 0,25}$ & $5,6^{* *}$ & $\frac{88,52 \pm 0,32}{59,09 \pm 0,81}$ & $8,7^{* *}$ & $\begin{array}{l}5,05 \pm 0,04 \\
5,09 \pm 0,01\end{array}$ & $1,3^{*}$ & $\begin{array}{c}0,24 \pm 0,001 \\
0,04 \pm 0,06\end{array}$ & $2,6^{*}$ & $\begin{array}{l}\underline{0,05 \pm 0,04} \\
0,01 \pm 0,01\end{array}$ & $1,2^{*}$ \\
\hline $20-30$ & $\frac{2,22 \pm 0,10}{1,29 \pm 0,17}$ & $5,0^{* *}$ & $\frac{45,08 \pm 0,20}{61,01 \pm 0,38}$ & $9,3^{* *}$ & $\frac{5,65 \pm 0,04}{4,74 \pm 0,18}$ & $4,9^{*}$ & $\frac{0,16 \pm 0,01}{0,02 \pm 0,01}$ & $2,1^{*}$ & $\frac{0,04 \pm 0,04}{0,01 \pm 0,01}$ & $1,6^{*}$ \\
\hline $30-40$ & $\frac{2,09 \pm 0,10}{1,15 \pm 0,13}$ & $5,7^{* *}$ & $\frac{46,09 \pm 0,44}{44,74 \pm 1,43}$ & $4,9^{*}$ & $\frac{5,30 \pm 0,06}{4,69 \pm 0,05}$ & $8,4^{* *}$ & $\frac{0,07 \pm 0,01}{0,03 \pm 0,01}$ & $5,3^{* *}$ & $\underline{0,06 \pm 0,02}$ & $2,2^{*}$ \\
\hline $40-50$ & $\frac{1,61 \pm 0,06}{1,47 \pm 0,24}$ & $1,5^{*}$ & $\frac{6,03 \pm 0,60}{41,92 \pm 3,75}$ & $8,2^{* *}$ & $\frac{4,71 \pm 0,08}{5,87 \pm 0,04}$ & $3,1^{*}$ & $\frac{0,03 \pm 0,01}{0,04 \pm 0,01}$ & $6,7^{* *}$ & $\frac{0,03 \pm 0,02}{0,02 \pm 0,01}$ & $1,5^{*}$ \\
\hline $50-60$ & $\frac{1,04 \pm 0,07}{1,44 \pm 0,11}$ & $3,2^{*}$ & $\frac{11,38 \pm 0,13}{53,91 \pm 0,69}$ & $6,7^{* *}$ & $\frac{4,73 \pm 0,09}{7,98 \pm 0,09}$ & $5,6^{* *}$ & $\frac{0,02 \pm 0,01}{0,01 \pm 0,01}$ & $2,9^{*}$ & $\frac{0,09 \pm 0,03}{0,02 \pm 0,02}$ & $1,3^{*}$ \\
\hline $60-70$ & $\frac{0,87 \pm 0,04}{1,19 \pm 0,09}$ & $3,1^{*}$ & $\frac{15,24 \pm 0,20}{49,06 \pm 0,76}$ & $12,9^{* * *}$ & $\frac{4,19 \pm 0,11}{8,92 \pm 0,07}$ & $6,2^{* *}$ & $\frac{0,01 \pm 0,02}{0,03 \pm 0,01}$ & $1,5^{*}$ & $\frac{0,01 \pm 0,02}{0}$ & - \\
\hline $70-80$ & $\frac{1,31 \pm 0,07}{1,31 \pm 0,09}$ & $0,8^{*}$ & $\frac{12,37 \pm 0,40}{49,76 \pm 0,42}$ & $14,8^{* * *}$ & $\frac{4,24 \pm 0,02}{6,61 \pm 0,04}$ & $3,2^{*}$ & $\frac{0,01 \pm 0,01}{0,02 \pm 0,01}$ & $4,2^{*}$ & $\frac{0,08 \pm 0,02}{0}$ & - \\
\hline $80-90$ & $\frac{0,70 \pm 0,06}{0,81 \pm 0,08}$ & $1,1^{*}$ & $\frac{18,57 \pm 0,19}{53,09 \pm 1,37}$ & $10,8^{* * *}$ & $\frac{3,74 \pm 0,05}{5,03 \pm 0,05}$ & $1,5^{*}$ & $\frac{0,01 \pm 0,02}{0,01 \pm 0,05}$ & $3,2^{*}$ & $\frac{0,05 \pm 0,03}{0}$ & - \\
\hline
\end{tabular}

Примечание: ${ }^{1}$ - над чертой агрохимические показатели почвы условно чистого мониторингового участка, под чертой - цеха по выплавке алюминия; ${ }^{*}-p<0,05,{ }^{* *}-p<0,01,{ }^{* * *}-p<0,001$.

В гумусово-аккумулятивном горизонте его количество было в 1,5-2,0 раза меньше, чем в аналогичных слоях зональной почвы. В нижележащих слоях горизонта лессовидных суглинков содержание гумуса или было статистически достоверно меньшим, чем в зональной почве (20-30, 30-40 см), или не отличалось от его количества в черноземе южном (40-50, 70-80, 80-90 см). Определение $p H$ водной вытяжки

Вісник Дніпропетровського університету. Біологія, екологія.

Vìsnik Dnìpropetrovs'kogo unìversitetu. Seriâ Bìologîa, ekologîâ Visnyk of Dnipropetrovsk University. Biology, ecology. Vìsn. Dnìpropetr. Unìv. Ser. Bìol. Ekol. 2007. 15(1).

ISSN 2310-0842 print ISSN 2312-301X online www.ecology.dp.ua 
почвы опытного участка позволило установить, что ее значение смещается в щелочную область $(8,60-8,74)$, в отличие от зональной почвы $(6,65-6,98)$. Чернозем южный по степени обеспечения подвижных форм фосфора можно отнести к почвам с высокой степенью его обеспечения. Содержание подвижных соединений фосфора колеблется от 88 до 142 мг на 100 г почвы. В переходном горизонте $B$ - колеблется в пределах 45-46, а в переходном горизонте $B C$ и горизонте $C$ уменьшается в 8 раз.

Изучение распределения фосфора в почвенном разрезе опытного участка показало, что в гумусово-аккумулятивном горизонте его содержание уменьшается практически в 3 раза, что объясняется особенностью морфологического строения почвы этого участка. За гумусовым слоем находится не переходный слой, а отсыпная зона грунта с большим количеством строительного мусора, поэтому слои 50-100 см имеют более стабильное содержание фосфора 57-60 мг. В других почвенных слоях его содержание достоверно не отличается от зональной почвы.

Значительно обеднена почва разреза нитратными и нитритными формами азота. Если в поверхностном слое чернозема обыкновенного было 0,76 мг $\mathrm{N}-\mathrm{NO}_{2} / 100$ г сухой почвы, то в почве разреза у цеха по выплавке алюминия данная характеристика снижается в 9,4 раза. Только на глубине 40 см и ниже количество азота нитритных форм сопоставимо с таковыми в зональной почве. Анализируя данные по распределению количества азота этих форм вниз по профилю разреза, можно сделать вывод, что начиная с глубины 10 см и ниже его содержание существенно не изменяется (см. табл.). Определение азота нитратных форм показало, что он содержится в слоях 0-10 и 50-60 см в количестве в 20,0 и 4,5 раза более низком, чем в зональной почве.

В почве промышленной площадки в несколько большем количестве, чем в черноземе южном, содержится азот аммонийных соединений. В поверхностном слое его содержание на $70 \%$ больше, чем в зональной почве. Однако в слоях 10-40 см отмечено его статистически достоверное уменьшение по сравнению с количеством в черноземе южном. Уже в слоях почвы 50-110 см его количество снова превышает таковое для зональной почвы (5,03-7,98 мг $N-N_{4}^{+} / 100$ г сухой почвы). Эту специфику распределения азота аммонийных соединений можно объяснить тем фактом, что начиная с 62 см почвенный профиль формируется из лессовидных суглинков, перемещенных с фрагментами почвы бывшего гумусово-аккумулятивного горизонта.

Выполненный агрохимический анализ почв разреза на мониторинговом участке у цеха по выплавке алюминия позволил установить, что содержание гумуса, азота нитратных и нитритных форм и фосфора (в поверхностном слое 0-20 см) в них ниже, чем в зональной почве. Содержание азота аммонийных соединений превышает аналогичные значения для чернозема южного.

\section{Выводы}

Почва мониторингового участка, испытывающая влияние выбросов алюминиевого производства, имеет более щелочную реакцию водной вытяжки, чем зональная $(8,60-8,95)$, что объясняется поступлением значительных количеств твердых фторсодержащих выбросов в эдафотопы. В поверхностных слоях почв (а для некоторых почвенных разрезов и по всему профилю) наблюдается уменьшение количества гумуса. При приближении к источнику эмиссий эта тенденция становится четко выраженной. В поверхностном слое почвы мониторинговых участков на промышленной площадке Запорожского алюминиевого комбината отмечена меньшая их обеспеченность фосфором подвижных форм, азотом нитратных и нитритных форм (в 1,52,0 раза) по сравнению с черноземом южным. Установлено повышенное содержание азота аммонийных соединений в поверхностных слоях почвы вблизи комбината. Это может быть объяснено присутствием незначительных количеств аммиака в промыш-

Вісник Дніпропетровського університету. Біологія, екологія.

Vìsnik Dnìpropetrovs'kogo unìversitetu. Serìa Bìologiâ, ekologîâ Visnyk of Dnipropetrovsk University. Biology, ecology. Vìsn. Dnìpropetr. Unìv. Ser. Bìol. Ekol. 2007. 15(1).

ISSN 2310-0842 print ISSN 2312-301X online www.ecology.dp.ua 
ленных выбросах предприятий, а в некоторых случаях - включением фрагментов почвы гумусово-аккумулятивного горизонта в эти слои.

\section{Библиографические ссылки}

1. Барановский А. 3. Накопление фтора в биологических объектах при длительном применении фосфорных удобрений на торфяно-болотных почвах / А. З. Барановский, Л. И. Панкрутская // Агрохимия. - 1992. - № 12. - С. 27-34.

2. Гапонюк Э. И. Фосфорные удобрения как возможный источник химического загрязнения почв / Э. И. Гапонюк, Ц.И.Бобовникова, Н.П.Кремленкова // Химия в сельском хозяйстве. - 1992. - № 12. - С. 40-42.

3. Грицан Н. П. Экологические основы природопользования / Н. П. Грицан, Н. В. Шпак, Г. Г. Шматков. - Д.: ИППЭ НАН Украины, 1998. - 409 с.

4. Гришко В. Н. Влияние загрязнения почв фтороводородом на некоторые агрохимические свойства чернозема обыкновенного / В. Н. Гришко, Л. Г. Долгова // Тез. докл. VIII съезда Всесоюзн. о-ва почвоведов. - Новосибирск, 1989. - Т. 3. - С. 290.

5. Кремленкова Н. П. Геохимическая оценка опасности фторидного загрязнения почв Восточной Европы // Почвоведение. - 1996. - № 9. - С. 1135-1141.

6. Моршина Т. А. Изменение свойств почв под влиянием фтора / Т. Н. Моршина, Т. П. Фанаскова // Почвоведение. - 1998. - № 3. - С. 21-26.

7. Практикум по агрохимии / Под ред. В. Г. Минеева. - М.: Изд-во МГУ, 1989. - 304 с.

8. Сараев В. Г. Содержание фтора в почвах Минусинской котловины в зоне воздействия алюминиевого завода // Почвоведение. - 2001. - № 2. - С. 94-97.

9. Omueti O. I. Fluoride adsorption by illinois soil / O. I. Omueti, R. L. Jones // Soil Sci. Soc. Amer Proc. - 2000. - Vol. 28. N 8. - P. 564-572.

10. Hung P. M. Mechanism of reaction of neutral fluoride solution with layer silicates and oxides of soil / P. M. Hung, U. L. Jackson // Soil Sci. Soc. Amer. Proc. - 1995. - Vol. 29, N 6. - P. 661-665.

Надійшла до редколегії 10.11.2006

Вісник Дніпропетровського університету. Біологія, екологія.

Vìsnik Dnìpropetrovs'kogo unìversitetu. Seriâ Bìologîa, ekologiâ

Visnyk of Dnipropetrovsk University. Biology, ecology. Vìsn. Dnìpropetr. Unìv. Ser. Bìol. Ekol. 2007. 15(1).

ISSN 2310-0842 print ISSN 2312-301X online www.ecology.dp.ua 